\title{
Population size, habitats and conservation of Marquesan Imperial Pigeon Ducula galeata
}

PASCAL VILLARD, MARIE-NOËL DE VISSCHER and GILLES BALANÇA

\begin{abstract}
Summary
Marquesan Imperial Pigeon Ducula galeata only survives on Nuku Hiva island in the Marquesas archipelago. It lives and nests mainly in small patches of forest with tall trees, in deep valleys. The population is likely to consist of only 80-150 birds. However, its forest habitat is in peril due to overgrazing, especially by goats, which precludes growth of young trees. Better control of feral herbivores should be a priority for the conservation of the species, as well as the cessation of poaching of this endangered pigeon. Introduced black rats Rattus rattus do not seem to be a threat for this bird.
\end{abstract}

\section{Introduction}

Marquesan Imperial Pigeon D. galeata (hereafter referred to as Upe, the local name) is one of the 36 species of the genus Ducula, all of which are distributed in the Pacific region. Of these, four are Near Threatened, six are Vulnerable, one Endangered and two (including Upe) Critically Endangered, according to IUCN criteria (BirdLife International 2000). Of the nine threatened species, six live on small islands. While Upe is today restricted to Nuku Hiva, an island in the Marquesas archipelago about 1,200 km north-east of Tahiti (French Polynesia), it occured on at least six other islands within a $2,500 \mathrm{~km}$ radius in prehistoric times (Steadman 1995).

Few data on Upe have been collected. When Prince Bonaparte first described the species it was already restricted to Nuku Hiva (Bonaparte 1855). Later, in 1922, the Whitney South Sea expedition spent about 40 days on Nuku Hiva to collect bird specimens, including Upe, which were also mentioned by Rollin (1929). Over the past 30 years, four population estimates of Upe have been carried out on Nuku Hiva (Holyoak 1975, Holyoak and Thibault 1984, Everett et al. 1996, Evva 1998). All but the latest survey spent less than one month on the island. During 2000, we performed a more intensive field study to collect initial data on the behaviour and breeding of the species, to refine spatial and ecological distribution and to assess the main reason for its decline. This paper presents our first results and proposes specific measures for Upe conservation.

\section{Study area}

Nuku Hiva is a volcanic island of $337 \mathrm{~km}^{2}$ (Figure 1), with three imbricated high ridges (the highest of which is Tekao, 1,224 $\mathrm{m}$ ), a large central plateau (Toovii) 


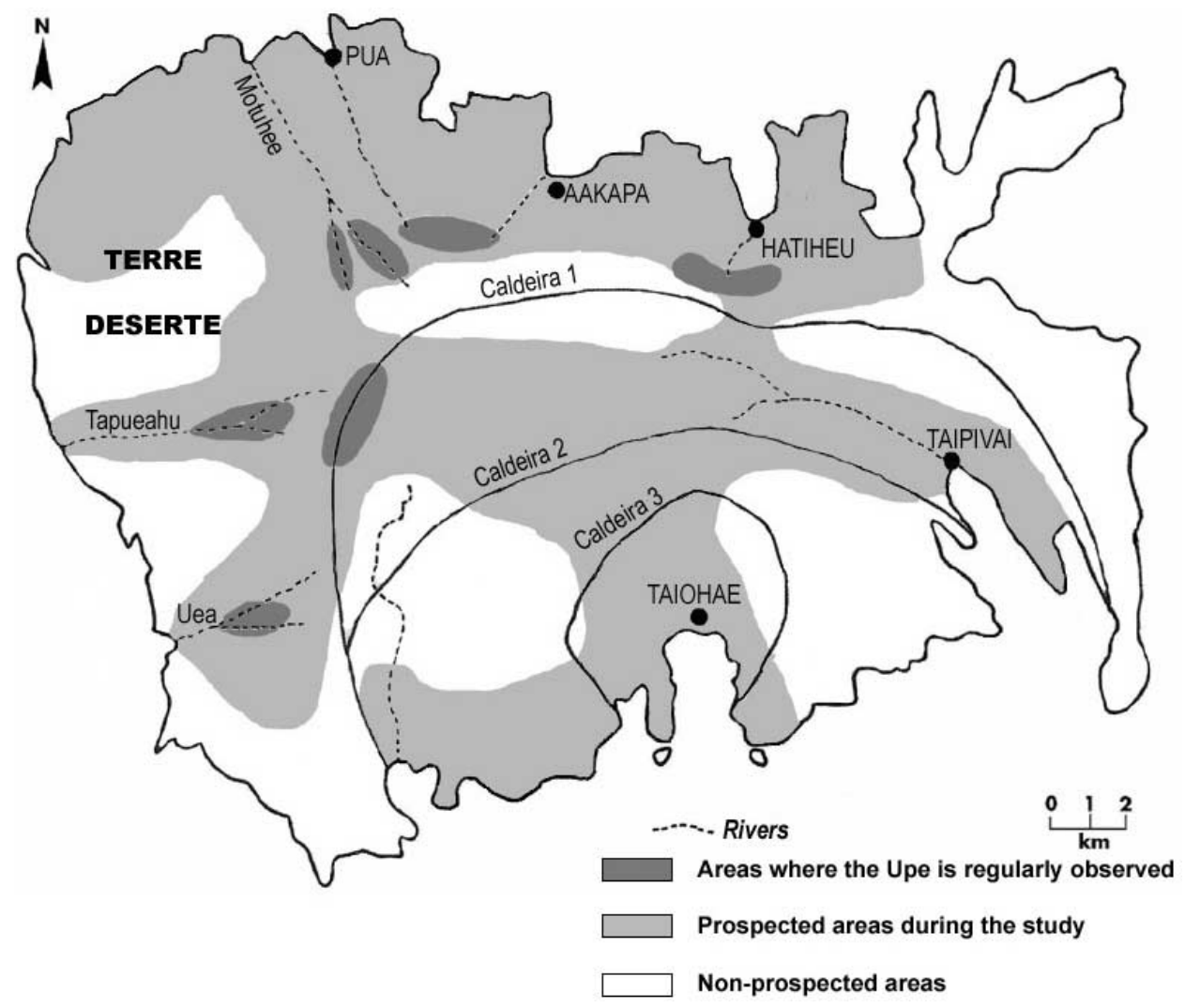

Figure 1. Distribution of the Upe on Nuku Hiva Island.

and some deep valleys between the bottom of the external ridge and the coast. Most of the area was originally covered by forest except the drier north-western plain "Terre Déserte", where shrub savanna is still predominant. Since the first colonization by man 1,500-2,000 years ago (Garanger 1993), the original landscape on Nuku Hiva has been modified substantially, especially by forest clearance for human settlement and agriculture. In 1774, when Captain Cook arrived on the Marquesan archipelago, the number of inhabitants was estimated between 78,650 and 90,500 (Sodter 1993). In 1926, only 2,000 inhabitants were censused (Rollin 1929), but by 2000, 8,000 inhabitants (2,500 on Nuku Hiva) lived on the Marquesas islands, and roads, airports and other facilities had been built. Moreover, between 1974 and 1989 , all natural vegetation on a large area of the main flat area of Nuku Hiva (plateau de Toovii, $850 \mathrm{~m}$ elevation) was cut down or burnt to be converted into grassland, and 1,100 ha were planted with Caribbean pines Pinus caribaea. The most recent vegetation map (Florence 1993) delimits vegetation units according to species association. In addition to the direct manmade modifications to the natural landscape (agriculture, fire, roads, buildings, etc.), introduced feral mammals (goats, pigs, etc.) have affected the vegetative cover in some parts of the island by overgrazing. This is particularly obvious on 
the higher part of the western and southern valleys outside the external ridge where totally eroded patches are called "colline rouge" (Florence 1993).

\section{Methods}

One of us (PV) stayed on Nuku Hiva from 20 April to 29 August 2000, and was joined by MV and GB for one week in April and four weeks in July, respectively. We visited most parts of the island (Figure 1 ) and especially every area where Upe had been recorded by previous visitors (Everett et al. 1996, Evva 1998). According to Evva (1998), who spent three months on the island, Upe appears to be distributed in subpopulations regularly observed in the same areas.

We spent from 2 to 15 days at each site either consecutively or intermittently. All bird observations or contacts were recorded (number of birds, activities such as feeding, calling, or perching, flight direction, etc.). The main vocalization is an unmistakable rasping call and the bird in flight is very obvious with its large wingspan averaging $94 \mathrm{~cm}$. For these reasons, Upe are easy to detect, both in the tree canopy and in flight. Habitat types used by Upe were characterized according to the vegetation map of Nuku Hiva (Florence 1993). Tree species used by birds to feed or to build nests were identified from samples by a botanist (J.-Y. Meyer) and agronomists working at the Service de l'Economie Rurale, Taiohae. All observed nests were described (height above ground, nest measurements through visual estimations, etc.). Finally, we interviewed local people to collect historical and other anecdotal information on the Upe.

\section{Results}

Age structure and morphometric data

Very early during our field study, we noted morphological differences between birds when perched, allowing us to distinguish three age classes: adults, subadults (like adults excepted for a less developed cere) and juveniles, with a brownish plumage and lacking the cere and white eyes. Approximately $14 \%$ of the recorded birds $(n=95)$ were considered to be less than one year old. As in most Ducula and other pigeon species, Upe do not show sufficient sexual dimorphism to differentiate males and females easily in the field. However, we had the opportunity to measure six individuals that were captured for translocation (five) or research (one). Based on measurements (Table 1), we assumed three birds were male and two female: wing length seemed strongly differentiated between the sexes, and there were differences also in tarsus length, body length and weight. In the field, when it was possible to observe groups of birds, we often saw some bigger Upe that we assumed to be males. Moreover, the sex of male number 3 was later confirmed by a genetic analysis (polymerase chain reaction) of the only blood sample we collected (R. Lecoq pers. comm.).

\section{Population distribution}

Upe regularly inhabited seven sites during our study (Figure 1). They lived in areas with tall trees but also perched on shrubs, especially to feed on guava 
Table 1. Morphometric measurements on six living Marquesan Imperial Pigeons captured during our study.

\begin{tabular}{lllllll}
\hline & \multicolumn{3}{c}{ Males } & \multicolumn{2}{c}{ Females } & Juvenile \\
\hline Number & 1 & 2 & 3 & 4 & 5 & 6 \\
Tarsus (mm) & 53.2 & 53.5 & 55.3 & 52.7 & 51.6 & 50.1 \\
Wing (mm) & 315 & 302 & 315 & 295 & 292 & 291 \\
Total length (mm) & 557 & 560 & 560 & 540 & 530 & 510 \\
Weight (g) & 600 & 660 & 690 & 550 & 590 & 440 \\
\hline
\end{tabular}

Psidium guajava fruits. They were mostly observed in Thespesia-Pisonia, MangiferaCoffea and Miscanthus vegetation and rarely, if ever, found in dry areas such as the "Terre Déserte" in the north-western part of the island. Information from reliable local sources indicated that they were observed only rarely in other areas such as the Taiohae Valley.

The same deep wooded valleys appeared to be inhabited during successive days, weeks or months by groups of birds whose size and age composition could change with time. During the day, Upe were mostly attracted by ripe fruits, which were systematically exploited. At Uea, a group of approximately 20 Upe was observed during May and June when ripe guava and Ficus prolixa fruits were abundant. In July, ripe fruits were scarce and a maximum of only five birds were still present.

Upe appeared to return to the same feeding and roosting places. At Hatiheu, a group of three to five birds including two juveniles was observed every evening during two weeks in July and again two and three weeks later. They fed on the same trees before perching on a tall tree where they spent the night. Once, an adult even showed territorial behaviour by chasing another adult (male number 3). At the same place, in April, eight Upe were observed in the evening, and in December, when many fruits of Ilang ilang Cananga odorata were ripe, more than 20 individuals fed during the day (Y. Katupa, pers comm.).

\section{Population size}

Upe have been counted in different parts of the island (Table 2). For areas visited several times, we have used the maximum number of Upe recorded during one visit. Since we are confident that we did not miss any important Upe sites, our data are a reliable sample of the total population. However, we do not know for certain how the total of 95 birds we recorded relates to the total Upe population size (see Discussion).

\section{Reproduction}

Thirty-three nests were discovered in the Motuhee (10), Tapueahu (11) and Uea (12) valleys. Most of them were old but five occupied nests were found. The first was found on 2 June (one egg). On August 18, in the Motuhee Valley, we observed two pairs of pigeons incubating one egg each, and two other nests each contained one young chick, one a few days and the other two weeks old. Nests were found on six tree species: Aleurites mollucana (three), Artocarpus altilis (two), 
Table 2. Number of Marquesan Imperial Pigeons observed in different sites.

\begin{tabular}{|c|c|c|c|c|}
\hline Areas & Habitat types ${ }^{a}$ & Total $^{\mathrm{b}}$ & Sub-adults & Juveniles \\
\hline Haahini $^{c}$ & Erythrina & 4 & & \\
\hline Matateiko & Erythrina & 6 & & \\
\hline Uea & Thespesia-Pisonia & 22 & 1 & 5 \\
\hline Tapueahu & Thespesia-Pisonia & 17 & & 1 \\
\hline Toovii & $\begin{array}{l}\text { Ilex-Cherodendron and } \\
\text { Hernandia-Cyathea }\end{array}$ & 7 & 1 & 1 \\
\hline Motuhee & Mangifera-Coffea and Miscanthus & 20 & 1 & 2 \\
\hline Pua & Mangifera-Coffea and Miscanthus & 4 & & \\
\hline Aakapa & Mangifera-Coffea and Miscanthus & 7 & & 1 \\
\hline Hatiheu & Mangifera-Coffea and Miscanthus & 8 & & 3 \\
\hline Total & & 95 & 3 & 13 \\
\hline
\end{tabular}

${ }^{a}$ Florence (1993); ${ }^{b}$ maximum number of different birds observed including adults, subadults and juveniles; ${ }^{\mathrm{C}} \mathrm{R}$. Sulpice (pers. comm.).

Ficus prolixa (eight), Hernandia nukuhivensis (one), Sapindus saponaria (one), Terminalia glabrata (18). Nests were strong constructions and mainly built high in the canopy, near the ends of small branches. They were located in patches of forest a few hundred $\mathrm{m}$ long by $100-200 \mathrm{~m}$ wide, on riverbanks in the upper parts of valleys with a canopy reaching around $20-25 \mathrm{~m}$ height. We did not look for nests in Aakapa and Pua areas but forests there appeared suitable. In Toovii, one nest was reported (Butaud 2000).

\section{Threats to Upe}

In 1944, according to local people there were many Upe at Aakapa (northern coast of Nuku Hiva) and hunters often brought back bags full of birds (M. Kimitete pers. comm.). In 1951, the Upe population seemed to be decreasing and, with the arrival of shotguns in the 1950s, this trend was amplified (M. Kimitete pers. comm.). In 1978-1979, the airport was built in "Terre Déserte" and workers took the opportunity to hunt Upe in the surrounding valleys such as Motuhee (R. Sulpice pers. comm.), even though bird hunting had been banned in French Polynesia since December 1967. At the time of our survey, if Upe poaching still occurred, people interviewed considered it only occasional. Hunting probably explains most of the Upe population decrease up to the time of our survey but other factors should also be assessed. Meteorological events are unlikely to provide a negative impact, because the Marquesas islands have not been subjected to hurricanes, at least for the period 1903-2001 (J. Trideau pers. comm.).

Domestic livestock introduced by human colonisation have become feral. While cattle and horses are at present largely controlled on Nuku Hiva, feral goats and pigs are abundant on some parts of the island, even if they do not reach the cloud forest at the top of the volcanic ridge. In one day we saw more than 80 goats in the Uea valley. The detrimental effects of goats and pigs on the natural vegetation are well known and in areas where Upe is found, big patches of natural forest have been destroyed, and there is poor natural forest regeneration. Black rats Rattus rattus were present everywhere that Upe were found in our study and we even trapped them at the foot of several trees with an occupied nest. 


\section{Discussion}

Population trends and present size

Various published sources and local information indicate that the Upe population decreased during the twentieth century. In 1922, during the Whitney expedition, the killing of 82 Upe (Quayle 1922, Beck 1923) is likely to have represented a significant part of the population. Of the birds killed, 59 came from the Tapueahu Valley, more than three times as many as that observed here in this study (17 birds). After the killings, "the Upe were not so abundant there" (Quayle 1922). In the present census about $10-20 \%$ of the total number of Upe seen was found in the Tapueahu valley. So, we can reasonably expect that at least several hundred birds were living on the island 80 years ago.

Available recent censuses of Upe in the literature cover a time span of about 25 years. Population estimates confirm the severity of the Upe population decrease since the 1920s, to about 200 birds at the end of the twentieth century (Table 3). However, only Evva (1998) presents details of his census method (point-counts) and the assumptions on which he builds his population estimate (proportion of singing birds and of missed and double-counted birds). Following this last study, BirdLife International (2000) estimated 250 birds remain. Census methods, study duration and ornithological experience have differed greatly among recent observers. Therefore, we agree with Evva (1998) and avoid stating any trend in Upe populations for the past three decades. In order to survey the Upe population, future censuses should repeat the same counts on the main sites as proposed by Evva (1998).

The total numbers of Upe seen or heard in the two most recent studies (Evva 1998 and our study) are very similar ( 85 and 95), despite the different approaches used. Higher numbers were obtained when fieldwork periods were longest, our study being even more intensive on each site (number of days in the field). Therefore we consider that the population size is at least 80 birds; the maximum estimates of 260 (Evva 1998) and 300 Upe (Everett et al. 1993) seem too high, as it is unlikely that we missed two thirds of the total population in our counts, or a site holding a significant number of birds. Moreover, it is possible that there was double counting in our surveys, so the present population size is likely to be only $80-150$ birds. The only way to provide a reliable estimate of the actual population would be to organize a simultaneous count in all the places where Upe are present. The small size of this island and the short distances between sites make it feasible if local people are involved.

Table 3. Marquesan Imperial Pigeon census results from 1972 to 2000.

\begin{tabular}{lllc}
\hline Authors & $\begin{array}{l}\text { Census } \\
\text { period }\end{array}$ & $\begin{array}{l}\text { Number of birds } \\
\text { observed }\end{array}$ & $\begin{array}{l}\text { Estimated } \\
\text { population }\end{array}$ \\
\hline Holyoak (1975) & Aug 1972 & 57 & $75-105$ \\
Holyoak and Thibault (1984) & During 1975 & & $200-400$ \\
Everett et al. (1996) & Oct 1993 & $50-58$ & $150-300$ \\
Evva (1998) & June-Aug 1998 & $85^{\mathrm{a}}$ & $220-260$ \\
Present study & Apr-Aug 2000 & 95 & $80-150$ \\
\hline
\end{tabular}

aseen or heard 
Whatever the population trend, it is worth noting that the species survives on the island and is still breeding in different areas, with a significant proportion of young individuals. To support this surviving population the main threats to the species should be controlled urgently.

\section{Threats and conservation measures}

At the time of the Whitney expedition, most human modifications of natural habitats had already occurred, yet Upe were still abundant. As powerful guns only reached the island in the 1950s, it is reasonable to assume that hunting and later poaching was a contributory factor in the decline in the Upe population from this time. Moreover, it is significant that Upe still survive only in the most remote areas of the island. We also found that Upe, like other fruit-eating pigeons, only lay one egg, suggesting they are long-lived (Clout et al. 1995). Therefore, any increase in adult mortality because of predators or poachers would have a substantial impact on the population's survival. If hunting pressure were now alleviated, as reported by local people, any future Upe population increases would likely be slow and unclear for several years.

Once the poacher problem is solved, Upe will also need sufficient suitable habitat for food and nesting. Deforestation for pasture and the planting of pines on the Toovii plateau removed a significant area of suitable habitat. Moreover, only a few tens of ha of forest, essential as nesting sites or roosting places, are still available in the valleys. Upe also feed there, even though they are well adapted to introduced fruit trees. Tree regeneration in these essential forest patches appears poor because of overgrazing by feral goats and the survival of those ageing forests is therefore of great concern. Holyoak (1973) considered that the number of goats has been growing since the 1970s and Evva (1998) found that goats and pigs were met everywhere. We agree with this last author and consider doubtful that any decrease in the feral game population has occurred, as asserted by some hunters. To allow growth of young trees, we recommend enclosing parts of those forests and controlling feral goats more effectively. Saving and expanding natural forests should be a priority in ensuring the conservation of the Upe on Nuku Hiva.

Introduced black rats, which are often blamed for a decrease in bird numbers or the extinction of other species on the islands (Seitre and Seitre 1992), arrived in Nuku Hiva around 1915 (Thibault and Meyer 2000, Thibault et al. 2002). The significant proportion of young pigeons observed during this study suggests that rats do not significantly jeopardize their breeding success. Adult pigeons are probably able to chase away rats from nests, as has been observed for New Zealand Pigeon Hemiphaga novaeseelandiae (M. Clout pers. comm.). However, a specific study on this potential predator is still needed to confirm this hypothesis. In the meantime, the possible threat of black rats on survival was one of the reasons for the Polynesian Ornithological Society (SOP) to transfer five Upe from Nuku Hiva to Ua Huka, an island close by free of black rats, in 2000 (Blanvillain et al. 2000). To evaluate the potential for survival and increase of the Upe population, we urgently need demographic analyses based on models, and more data on mortality, life expectancy and breeding success. 


\section{Acknowledgements}

The French Ministry for Land Management and Environment financed this work. In Polynesia, the Rural Development Service provided accommodation and a vehicle. We would like to thank J.-Y. Meyer, J.-P. Malet and R. Sulpice for their botanical expertise, C. Blanvillain who allowed us to measure five birds captured for translocation, J. Trideau (Météo France) for meteorological information, P. Sweet (AMNH) for access to the Whitney expedition documents (Department of Ornithology archives), R. Lecoq for the genetic analysis, and J.-C. Thibault as well as two anonymous referees, for their very useful comments on the manuscript.

\section{References}

Bonaparte, J. (1855) Notes sur les oiseaux des îles Marquises, et particulièrement sur le genre Serresius. C.R. Acad. Sci. Paris 41: 1109-1113.

Beck, R. H. (1923) Journal of the Whitney South Sea Expedition of the American Museum of Natural History, September 1920 - June 1923. AMNH.

BirdLife International (2000) Threatened birds of the world. Barcelona and Cambridge, U.K.: Lynx Edicions and BirdLife International.

Blanvillain C., Thorsen M. and Sulpice, R. (2000) Le Upe vole à nouveau sur Ua Huka. Te Manu 32: 3-5.

Butaud, J.-F. (2000) Quelques informations complémentaires sur la biologie du Upe. Te Manu 30: 2.

Clout, M. N., Karl, B. J., Pierce R. J. and Robertson, H. A. (1995) Breeding and survival of New Zealand Pigeons Hemiphaga novaeseelandiae. Ibis 137: 264-271.

Everett W., Varney A. and Burr, T. (1996) Report on field survey for the Upe (Nuku Hiva Imperial Pigeon) Ducula galeata. Unpublished report, Zoological Society of San Diego, San Diego, CA.

Evva, J. (1998) Etude du 'Upe' Ducula galeata, carpophage endémique de l'archipel des Marquises (Polynésie française) et mesures de conservation. Rapport de DESS, Montpellier.

Florence, J. (1993) La végétation de quelques îles de la Polynésie française. Atlas de la Polynésie française. Paris: ORSTOM.

Garanger, J. (1993) Le peuplement ancien. Atlas de la Polynésie française. Paris: ORSTOM.

Holyoak, D. T. (1973) Endangered land-birds in French Polynesia. Biol. Conserv. 5: 231232.

Holyoak, D. T. (1975) Les oiseaux des îles Marquises. ORFO 45: 341-366.

Holyoak, D. T. and Thibault, J.-C. (1984) Contribution à l'étude des oiseaux de Polynésie orientale. Série A, Zoologie. Paris: Ed. du Muséum.

Quayle, E. Q. (1922) Whitney South Sea Expedition of the American Museum of Natural History. Book XXXI: second cruise of the "France" to Huapu, Nukuhiva (Marquesas) September 12-October 1922; Book XXXII: to Nukuhiva, Hivaoa (Marquesas) October 3November 7. AMNH.

Rollin, L. (1929) Les îles Marquises. Société d'éditions géographiques maritimes et coloniales.

Seitre, R. and Seitre, J. (1992) Causes of land-bird extinctions in French Polynesia. Oryx 26: $215^{-222 .}$

Sodter, F. (1993) L'histoire démographique. Atlas de la Polynésie française. Paris: ORSTOM.

Steadman, D. W. (1995) Prehistoric extinctions of Pacific island birds: biodiversity meets zooarcheology. Science 267: 1123-1131.

Thibault, J.-C. and Meyer, J.-Y. (2000) L'arrivée du rat noir (Rattus rattus) à Fatuiva (îles Marquises). Te manu 31: 5-7. 
Thibault, J.-C., Martin, J.-L., Penloup, A. and Meyer, J.-Y. (2002). Understanding the decline and extinction of Monarchs (Aves) in Polynesian Islands. Biol. Conserv. 108: 161174 .

PASCAL VILLARD

10 rue de la Gare, 39100 Andelot en Montagne - France.

MARIE-NOËL DE VISSCHER ${ }^{1}$ and GILLES BALANÇA

Cirad/Emvt-Econap, TA30/F, Campus International de Baillarguet, 34398 Montpellier cedex 5, France

${ }^{1}$ Author for correspondence.

Received 9 May 2002; revision accepted 26 March 2003 
